\title{
Struktur Komunitas Mikroartropoda Tanah di Lahan Pertanian Organik dan Anorganik di Desa Batur Kecamatan Getasan Salatiga
}

\author{
Shifa Aulia Husna, Mochamad Hadi, dan Rully Rahadian \\ Jurusan Biologi, Fakultas Sains dan Matematika, UniversitasDiponegoro \\ Jalan. Prof. H. Soedharto, SH, Tembalang,Semarang, Jawa Tengah, Indonesia 50275; \\ E-mail: shifa.auliahusna@gmail.com, hadi_tamid@yahoo.co.id, dan rrahadian@gmail.com
}

\begin{abstract}
Soil microarthropods is a arthropods that have an important role in decomposing organic materials and soil nutrients. On the farmland there is organic materials content and soil nutrients that abundants enough, because the addition of manure as a source of energy in the ground. The research was conducted in August-October 2015 took place in the field of organic and inorganic farmland in the Batur Village, Getasan Sub-district, Salatiga. This study aimed to examine the soil microarthropods community structure in organic and inorganic farmland as well as the effect of chemical and physical environmental factors to community structure of soil microarthropods. The study was conducted with samples of soil sampling method (PCT) and extracted using Barlese Funnel Extractor. Statistically show that diversity of soil microarthropods between organic and inorganic farmland are not significantly different. There is found 28 taxa of soil microarthropods in organic farmland and 23 taxa in inorganic. The highest total individual density of the taxa are exist in the organic farmland ( $\left.2260 \mathrm{individual} / \mathrm{m}^{2}\right)$. The highest abundance of soil microarthropods taxa in inorganic farmland are Carabidae $(26,55 \%)$ dan Prostigmata $(13,27 \%)$, while in inorganic farmland are Carabidae (17,24\%) dan larva Coleoptera (13,79\%). The evenness of soil microarthropods taxa in organic farmland are much low compared with inorganicfarmland, because there is a dominant taxa (Carabidae). There is an influence relation between the chemical and physical environmental factors including water content, porosity, nutrient, and organic materials with community structure of soil microarthropods.
\end{abstract}

Key words: Community structure, Soil microarthropods, Organic and inorganic farmland

\begin{abstract}
Abstrak
Mikroartropoda tanah merupakan artropoda tanah yang memiliki peran penting dalam mendekomposisi bahan organik dan unsur hara di dalam tanah. Pada lahan pertanian terdapat kandungan bahan organik dan unsur hara yang cukup melimpah, karena dilakukan penambahan pupuk sebagai sumber energi pada tanah. Penelitian ini dilakukan pada bulan Agustus-Oktober 2015 bertempat di lahan pertanian organik dan anorganik di Desa Batur, Kecamatan Getasan, Salatiga. Penelitian bertujuan untuk mengkaji struktur komunitas mikroartropoda tanah di lahan pertanian organik dan anorganik serta pengaruh faktor fisik kimia lingkungan terhadap struktur komunitas mikroartropoda tanah. Penelitian dilakukan dengan metode pencuplikan sampel tanah (PCT)dan ekstraksi menggunakan Barlese Funnel Extractor. Secara statistik keanekaragaman mikroartropoda tanah antara lahan pertanian organik dengan anorganik tidak berbeda nyata. Ditemukan 28 taksa mikroartropoda tanah di lahan pertanian organik dan 23 taksa di anorganik. Total kepadatan individu taksa tertinggi ada pada lahan pertanian organik $\left(2260 \mathrm{individu} / \mathrm{m}^{2}\right)$. Kelimpahan mikroartropoda tanah tertinggi di lahan pertanian organik adalah Carabidae (26,55\%) dan Prostigmata $(13,27 \%)$, sedangkan di lahan pertanian anorganik adalah Carabidae (17,24\%) dan larva Coleoptera (13,79\%). Tingkat kemerataan mikroartropoda tanah di lahan pertanian organik lebih rendah dibandingkan dengan anorganik, karena terdapat taksa yang mendominasi (Carabidae). Terdapat hubungan antara faktor fisik kimia lingkunganseperti kadar air, porositas, unsur hara, dan bahan organik dengan struktur komunitas mikroartropoda tanah.
\end{abstract}

Kata kunci:Struktur komunitas, Mikroartropoda tanah, Lahan pertanian organik dan anorganik 


\section{PENDAHULUAN}

Indonesia merupakan negara agraris dengan sumber kekayaan alam yang melimpah. Pertanian merupakan salah satu kegiatan yang memanfaatkan sumber daya hayati untuk menghasilkan kebutuhan pokok pangan. Sektor pertanian di Indonesia merupakan sektor terpenting khususnya dalam memproduksi sumber daya tanaman pangan. Sejauh ini di dalam sektor pertanian dikenal dengan dua macam sistem, yaitu sistem pertanian organik dan anorganik.

Sistem pertanian organik merupakan "hukum pengembalian (law of return)" yang berarti suatu sistem yang berusaha untuk mengembalikan semua jenis bahan organik ke dalam tanah, baik dalam bentuk residu dan limbah pertanian maupun ternak yang selanjutnya bertujuan memberikan makanan pada tanaman (Sutanto, 2002). Dalam pertanian organik sistem pembudidayaan tanamannya menggunakan bahanbahan organik alami tanpa bahan-bahan kimia sintetik (Mayrowani, 2012).

Sistem pertanian anorganik merupakan pertanian yang menggunakan pestisida dan pupuk kimia sintetik (Sutanto, 2002).Keuntungan dari sistem pertanian anorganik dengan menggunakan pupuk kimia sintetik dapat memberikan berbagai zat makanan bagi tanaman dalam jumlah yang cukup. Pupuk kimia sintetik mudah larut dalam air sehingga unsur hara yang dikandung mudah tersedia bagi tanaman (Gliessman, 2007). Menurut Sukardi (2012), penggunaan pupuk kimia sintetik secara intensif dengan tujuan menyuburkan tanah akan memberikan dampak negatif pada kualitas kesuburan tanah, penurunan tingkat produktivitas lahan, rusaknya sistem hidrologi, pencemaran di lingkungan dan hilangnya diversitas genetik berbagai jenis flora dan fauna tanah.

Menyadari dampak negatif dari penerapan sistem pertanian anorganik ini, maka dicari alternatif pertanian yang lebih aman, yaitu dengan mengembangkan sistem pertanian organik yang ramah lingkungan. Manfaat dari penerapan pertanian organik sudah terbukti dari berbagai hasil penelitian, meliputi aspek kesehatan pangan, kesehatan lingkungan, perbaikan struktur tanah, siklus mineral, dan kesuburan tanah. Selain itu, penerapan pertanian organik juga dapat mendorong stabilitas agroekosistem dan kelestarian lingkungan (Anggoro, 2003).

Salah satu bagian kelompok terbesar dari fauna tanah yang hidup di dalam tanah adalah mikroartropoda tanah. Mikroartropoda tanah merupakan komponen penting dari ekosistem tanah yang jumlah individu jenisnya sangat melimpah dan beranekaragam. Mikroartropoda tanah dengan jumlah mereka yang sangat melimpah memainkan peran penting dalam beberapa proses yang terjadi di dalam tanah seperti dekomposisi bahan organik, siklus hara dan energi serta proses pembentukan tanah (Lee \& Pankhurst, 1992; Doles et al., 2001; Parisi et al., 2005).

Bahan organik berperan sebagai sumber energi bagi kebanyakan biota tanah (Sugiyarto, 2000), seperti mikroartropoda tanah. Penggunaan pupuk dan pestisida organik di pertanian organik berdampak pada penambahan kandungan sumber energi bahan organik alami di tanah yang bermanfaat bagi produktivitas tanaman dan komunitas mikroartropoda tanah, sedangkan penambahan pupuk dan pestisida kimia sintetik pada lahan pertanian anorganik juga berdampak pada rendahnya kandungan sumber energi bahan organik alami bagi komunitas mikroartropoda tanah di lahan pertanian anorganik.

Berdasarkan perbedaan di atas, penerapan sistem pertanian anorganik berpotensi mengganggu keberadaan struktur komunitas mikroartropoda tanah yang ada di dalam tanah. Oleh karena itu, perlu dilakukan penelitian untukmengkaji struktur komunitas mikroartropoda tanah di lahan pertanian organik dan anorganik serta pengaruhfaktor fisik kimia lingkungan terhadap struktur komunitas mikroartropoda tanah di lahan pertanian organik dan anorganik.

\section{BAHAN DAN METODE}

Indonesia merupakan negara agraris dengan sumber kekayaan alam yang melimpah. Pertanian merupakan salah satu kegiatan yang memanfaatkan sumber daya hayati untuk menghasilkan kebutuhan pokok pangan. Sektor pertanian di Indonesia merupakan sektor terpenting khususnya dalam memproduksi sumber daya tanaman pangan. Sejauh ini di dalam sektor pertanian dikenal dengan dua macam sistem, yaitu sistem pertanian organik dan anorganik. 
Sistem pertanian organik merupakan "hukum pengembalian (law of return)" yang berarti suatu sistem yang berusaha untuk mengembalikan semua jenis bahan organik ke dalam tanah, baik dalam bentuk residu dan limbah pertanian maupun ternak yang selanjutnya bertujuan memberikan makanan pada tanaman (Sutanto, 2002). Dalam pertanian organik sistem pembudidayaan tanamannya menggunakan bahanbahan organik alami tanpa bahan-bahan kimia sintetik (Mayrowani, 2012).

Sistem pertanian anorganik merupakan pertanian yang menggunakan pestisida dan pupuk kimia sintetik (Sutanto, 2002).Keuntungan dari sistem pertanian anorganik dengan menggunakan pupuk kimia sintetik dapat memberikan berbagai zat makanan bagi tanaman dalam jumlah yang cukup. Pupuk kimia sintetik mudah larut dalam air sehingga unsur hara yang dikandung mudah tersedia bagi tanaman (Gliessman, 2007). Menurut Sukardi (2012), penggunaan pupuk kimia sintetik secara intensif dengan tujuan menyuburkan tanah akan memberikan dampak negatif pada kualitas kesuburan tanah, penurunan tingkat produktivitas lahan, rusaknya sistem hidrologi, pencemaran di lingkungan dan hilangnya diversitas genetik berbagai jenis flora dan fauna tanah.

Menyadari dampak negatif dari penerapan sistem pertanian anorganik ini, maka dicari alternatif pertanian yang lebih aman, yaitu dengan mengembangkan sistem pertanian organik yang ramah lingkungan. Manfaat dari penerapan pertanian organik sudah terbukti dari berbagai hasil penelitian, meliputi aspek kesehatan pangan, kesehatan lingkungan, perbaikan struktur tanah, siklus mineral, dan kesuburan tanah. Selain itu, penerapan pertanian organik juga dapat mendorong stabilitas agroekosistem dan kelestarian lingkungan (Anggoro, 2003).

Salah satu bagian kelompok terbesar dari fauna tanah yang hidup di dalam tanah adalah mikroartropoda tanah. Mikroartropoda tanah merupakan komponen penting dari ekosistem tanah yang jumlah individu jenisnya sangat melimpah dan beranekaragam. Mikroartropoda tanah dengan jumlah mereka yang sangat melimpah memainkan peran penting dalam beberapa proses yang terjadi di dalam tanah seperti dekomposisi bahan organik, siklus hara dan energi serta proses pembentukan tanah (Lee \& Pankhurst, 1992; Doles et al., 2001; Parisi et al., 2005).

Bahan organik berperan sebagai sumber energi bagi kebanyakan biota tanah (Sugiyarto, 2000), seperti mikroartropoda tanah. Penggunaan pupuk dan pestisida organik di pertanian organik berdampak pada penambahan kandungan sumber energi bahan organik alami di tanah yang bermanfaat bagi produktivitas tanaman dan komunitas mikroartropoda tanah, sedangkan penambahan pupuk dan pestisida kimia sintetik pada lahan pertanian anorganik juga berdampak pada rendahnya kandungan sumber energi bahan organik alami bagi komunitas mikroartropoda tanah di lahan pertanian anorganik.

Berdasarkan perbedaan di atas, penerapan sistem pertanian anorganik berpotensi mengganggu keberadaan struktur komunitas mikroartropoda tanah yang ada di dalam tanah. Oleh karena itu, perlu dilakukan penelitian untukmengkaji struktur komunitas mikroartropoda tanah di lahan pertanian organik dan anorganik serta pengaruhfaktor fisik kimia lingkungan terhadap struktur komunitas mikroartropoda tanah di lahan pertanian organik dan anorganik.

\section{HASIL DAN PEMBAHASAN}

Hasil penelitian menunjukkan bahwa mikroartropoda tanah di lahan pertanian organik didapatitotal kepadatannya2260 individu $/ \mathrm{m}^{2}$ yang terdiri dari 28 taksa, sedangkan di lahan pertanian anorganik ditemukan mikroartropoda tanah dengantotal kepadatan 1160 individu/m² dari 23 taksa (Tabel 1.).

Kepadatan mikroartropoda tanah di lahan pertanian organik lebih tinggi dibandingkan dengan lahan pertanian anorganik (Tabel 1.). Di lahan pertanian organik, kepadatan individu $/ \mathrm{m}^{2}$ tertinggi pertama ada pada Carabidae sebanyak 600 individu $/ \mathrm{m}^{2}$ dan tertinggi kedua dari Prostigmata sebanyak 300 individu $/ \mathrm{m}^{2}$, diikuti Mesostigmata, Oribatida, Cicadellidae, larva Coleoptera, Formicidae, dan Scelionidae dengan kepadatan berkisar antara 100-120 individu/ $\mathrm{m}^{2}$ (Tabel 1.).

Pada lahan pertanian anorganik, kepadatan individu $/ \mathrm{m}^{2}$ tertinggi ada pada Carabidae sebanyak 200 individu/ $\mathrm{m}^{2}$, diikuti larva Coleoptera sejumlah 160 individu $/ \mathrm{m}^{2}$. Kepadatan taksa mikroartropoda 
tanah lainnya di lahan pertanian anorganik berkisar antara 80-20 individu/ $\mathrm{m}^{2}$ (Tabel 1.).

Ordo Coleoptera famili Carabidae ditemukan dengan nilai kepadatan individu $/ \mathrm{m}^{2}$ yang sama-sama tinggi di lahan pertanian organik dan anorganik (Tabel 1). Hal ini disebabkan karena Carabidae bersifat sebagai predator kemungkinan dapat beradaptasi dengan baik di lingkungan manapun selama di dalamnya terdapat sumber makanan yang mendukung. Tingginya kepadatan Carabidae juga dibuktikan dengan perkembangbiakan dari ordo Coleoptera famili Carabidae yang tinggi sebagai bukti ditemukannya larva Coleoptera dalam jumlah yang tinggi di kedua lahan pertanian (Tabel 1.).

Kepadatan mikroartropoda tanah tertinggi kedua di lahan pertanian organik ada pada Acari Prostigmata. Prostigmata merupakan Acari yang jumlah taksanya ditemukan melimpah di tanah. Acari memiliki kemampuan beradaptasi yang sangat baik dan berperan sebagai dekomposer bahan organik serta siklus hara di dalam tanah (Samudra, 2013), sehingga pada lahan pertanian organik nilai kepadatannya tinggi (Tabel 1.). Hasil pengukuran kadar bahan organik pada lahan pertanian organik lebih tinggi dibandingkan dengan kadar bahan organik di lahan pertanian anorganik (Tabel 3.) sehingga di lahan pertanian organik nilai kepadatan Acari Prostigmata sebagai dekomposer tinggi. Semakin tinggi nilai kepadatan, berarti semakin banyak pula jumlah individu taksa yang menempati area tersebut.

Kepadatan mikroartropoda tanah pada suatu daerah dapat dipengaruhi oleh beberapa faktor, diantaranya: faktor fisik-kimia, sifat mikroartropoda tanah, struktur tanah, kandungan bahan organik pada tanah, dan komposisi vegetasi (Trewavas, 2007).

Tabel 1. Kepadatan, kekayaan, kelimpahan relatif, keanekaragaman, kemerataan, dan kesamaan taksa mikroartropoda tanah di lahan pertanian organik dan anorganik.

\begin{tabular}{|c|c|c|c|c|c|c|c|c|}
\hline \multicolumn{3}{|c|}{ Mikroartropoda Tanah } & \multicolumn{3}{|c|}{ Organik } & \multicolumn{3}{|c|}{ Anorganik } \\
\hline Ordo & Taksa & Peranan & & $\begin{array}{l}\text { Di } \\
\%)\end{array}$ & $\mathbf{K}$ & & $\begin{array}{l}\mathbf{i} \\
\text { (\%) }\end{array}$ & $\mathbf{K}$ \\
\hline \multirow[t]{3}{*}{ Acari } & Mesostigmata & Dekomposer & 5,31 & $* * * *$ & 120 & 1,72 & $* * *$ & 20 \\
\hline & Oribatida & Fungivora & 4,42 & $* * * *$ & 100 & 0 & & 0 \\
\hline & Prostigmata & Dekomposer & 13,27 & $* * * * *$ & 300 & 1,72 & $* * *$ & 20 \\
\hline \multirow[t]{4}{*}{ Collembola } & Isotomidae & Dekomposer & 0 & & 0 & 3,45 & $* * * *$ & 40 \\
\hline & Entomobryidae & Dekomposer & 0,88 & $* *$ & 20 & 0 & & 0 \\
\hline & Poduromorpha & Dekomposer & 2,65 & $* * *$ & 60 & 0 & & 0 \\
\hline & Symphypleona & Dekomposer & 0,88 & $* *$ & 20 & 0 & & 0 \\
\hline \multirow[t]{6}{*}{ Coleoptera } & Carabidae & Predator & 26,55 & $* * * * *$ & 600 & 17,24 & $* * * * *$ & 200 \\
\hline & Chrysomelidae & Herbivora & 0 & & 0 & 1,72 & $* * *$ & 20 \\
\hline & Lathridiidae & Predator & 0 & & 0 & 3,45 & $* * * *$ & 40 \\
\hline & Leoididae & Dekomposer & 3,54 & $* * * *$ & 80 & 5,17 & $* * * *$ & 60 \\
\hline & Staphyilinidae & Predator & 0,88 & $* *$ & 20 & 3,45 & $* * * *$ & 40 \\
\hline & Larva Coleoptera & Herbivora & 4,42 & $* * * *$ & 100 & 13,79 & $* * * * *$ & 160 \\
\hline Diplura & Japygidae & Dekomposer & 0 & & 0 & 3,45 & $* * * *$ & 40 \\
\hline \multirow[t]{8}{*}{ Diptera } & Anthomyzidae & Herbivora & 0,88 & $* *$ & 20 & 0 & & 0 \\
\hline & Cecidomyiidae & Herbivora & 3,54 & $* * * *$ & 80 & 1,72 & $* * *$ & 20 \\
\hline & Ceratopogonidae & Predator & 0 & & 0 & 3,45 & $* * * *$ & 40 \\
\hline & Ephydridae & Herbivora & 1,77 & $* * *$ & 40 & 0 & & 0 \\
\hline & Phoridae & Herbivora & 0,88 & $* *$ & 20 & 1,72 & $* * *$ & 20 \\
\hline & Psychodidae & Parasitoid & 0 & & 0 & 5,17 & $* * * *$ & 60 \\
\hline & Sciaridae & Herbivora & 0,88 & $* *$ & 20 & 0 & & 0 \\
\hline & Larva Diptera & Parasitoid & 0 & & 0 & 1,72 & $* * *$ & 20 \\
\hline Hemiptera & Miridae & Predator & 0 & & 0 & 1,72 & $* * *$ & 20 \\
\hline \multirow[t]{2}{*}{ Homoptera } & Aleyrodidae & Predator & 0,88 & $* *$ & 20 & 0 & & 0 \\
\hline & Cicadellidae & Predator & 5,31 & $* * * *$ & 120 & 1,72 & $* * *$ & 20 \\
\hline \multirow[t]{2}{*}{ Hymenoptera } & Aphelinidae & Parasitoid & 1,77 & $* * *$ & 40 & 0 & & 0 \\
\hline & Eurytomidae & Parasitoid & 1,77 & $* * *$ & 40 & 0 & & 0 \\
\hline
\end{tabular}




\begin{tabular}{|c|c|c|c|c|c|c|c|c|}
\hline & Formicidae & Predator & 5,31 & $* * * *$ & 120 & 0 & & 0 \\
\hline & Mymaridae & Parasitoid & 3,54 & $* * * *$ & 80 & 0 & & 0 \\
\hline & Scelionidae & Parasitoid & 4,42 & $* * * *$ & 100 & 5,17 & $* * * *$ & 60 \\
\hline \multirow[t]{2}{*}{ Lepidoptera } & Gelechiidae & Herbivora & 0,88 & $* *$ & 20 & 6,90 & $* * * *$ & 80 \\
\hline & Tineidae & Herbivora & 0,88 & $* *$ & 20 & 0 & & 0 \\
\hline \multirow[t]{4}{*}{ Psocoptera } & Philotarsidae & Predator & 0 & & 0 & 1,72 & $* * *$ & 20 \\
\hline & Liposcelidae & Predator & 0 & & 0 & 3,45 & $* * * *$ & 40 \\
\hline & Trogiidae & Predator & 0,88 & $* *$ & 20 & 0 & & 0 \\
\hline & Psocoptera & Predator & 0,88 & $* *$ & 20 & 0 & & 0 \\
\hline Thysanoptera & Thripidae & Predator & 1,77 & $* * *$ & 40 & 6,90 & $* * * *$ & 80 \\
\hline Thysanura & Lepismatidae & Dekomposer & 0 & & 0 & 3,45 & $* * * *$ & 40 \\
\hline \multirow[t]{6}{*}{ Holometabola lainnya } & Holometabola & Belum diketahui & 0,88 & $* *$ & 20 & 0 & & 0 \\
\hline & Total K & & & & 2260 & & & 1160 \\
\hline & $\mathbf{H}^{\prime}$ & & & 2,74 & & & 2,85 & \\
\hline & $\mathbf{S}$ & & & 28 & & & 23 & \\
\hline & e & & & 0,82 & & & 0,91 & \\
\hline & IS & & & & & & & \\
\hline
\end{tabular}

Keterangan:

$\mathrm{K}=$ Kepadatan $/ \mathrm{m}^{2}$, Di = Indeks kelimpahan relatif, $\mathrm{H}^{\prime}=$ Indeks keanekaragaman, $\mathrm{S}=$ Kekayaan taksa, e $=$ Indeks kemerataan, IS = Indeks kesamaan.

Kriteria Di $(\%)$ = Dominan"--", Subdominan"-", Resenden"-", Subresenden", Sporadik"

Kelimpahan mikroartropoda tanah yang ditemukan dominan di lahan pertanian organik adalah Carabidae (26,55\%) dan Prostigmata $(13,27 \%)$, sedangkan di lahan pertanian anorganik adalah Carabidae $(17,24 \%)$ dan larva Coleoptera $(13,79 \%)$.Kelimpahan famili Carabidae dari ordo Coleoptera di lahan pertanian organik dan anorganik ditemukan sama-sama menempati posisi tertinggi (Tabel 1.). Menurut Coleman et al. (2004), ordo Coleoptera termasuk kelompok mikroartropoda tanah yang secara permanen hidup di dalam tanah pada berbagai tingkat kedalaman tanah (permanent residents). Coleoptera di lahan pertanian dapat mencegah kerusakan pada tanaman akibat serangan hama karena sifatnya sebagai predator memangsa serangga hama yang merugikan bagi tanaman pertanian.

Acari Prostigmata juga menunjukkan tingkat kelimpahan dominan yang tinggi. Menurut Wallwork (1970), ada 4 kelompok Acari utama yang melimpah di tanah, yaitu Oribatida, Prostigmata, Mesostigmata, dan Astigmata. Prostigmata merupakan Acari yang ditemukan melimpah kedua setelah Oribatida. Akan tetapi, berdasarkan hasil penelitian di lahan pertanian organik ini Oribatida $(4,42 \%)$ ditemukan subdominan dibandingkan Prostigmata yang dominan (13,27\%). Menurut Wallwork (1970), hal ini dikarenakan sifat dari Oribatida sebagai fungivora yang lebih menyukai habitat tanah yang tidak terganggu atau tidak intensif mengalami aktivitas perubahan pada tanah.

Ada beberapa taksa mikroartropoda tanah yang berperan terhadap kesuburan tanah dengan cara mendekomposisi bahan organik dan unsur hara tanah, yaitu dari anggota Acari dan Collembola.Hasil penelitian menunjukkan bahwa jumlah mikroartropoda tanah Collembola yang ditemukan di lahan pertanian organik lebih tinggi dibandingkan dengan yang ditemukan di anorganik (Tabel 1.). Bersama dengan Acari, Collembola mendekomposisi bahan organik di dalam tanah untuk kemudian diubah oleh mikrobia menjadi senyawa yang dapat diserap tanaman.

Collembola dikenal sebagai organisme yang hidup di tanah dan memiliki peran penting seperti Acari dalam merombak bahan organik tanah. Dalam ekosistem pertanian Collembola terdapat dalam jumlah yang melimpah dan merupakan pakan alternatif bagi berbagai jenis predator (Greenslade et al., 2000).

Sesuai hasil penelitian dimana di lahan pertanian organik jumlah taksa dari predatornya tinggi. Hal ini didukung dengan keberadaan dari Collembola yang melimpah di lahan pertanian organik. Menurut Indriyati \& Wibowo (2008), kelimpahan Collembola sangat ditentukan oleh sistem pertanian yang diterapkan di lahan tersebut. Sistem pertanian dengan aplikasi pestisida secara berlebihan dapat menekan populasi dari 
Collembola. Sebaliknya, sistem pertanian yang ramah lingkungan seperti sistem pertanian organik akan menciptakan keadaan yang mendukung bagi kelangsungan hidup Collembola. Selain itu, Collembola juga berperan sebagai penyangga (buffer) untuk mempertahankan kehidupan serangga predator.

Indeks keanekaragaman menunjukkan

bahwa kedua lahan pertanian memiliki keanekaragaman mikroartropoda tanah yang sedang ( $\mathrm{H}^{\prime}$ 1,5-3,5). Pembuktian menggunakan perhitungan uji t-Hutchison menunjukkan nilai $t$ hitung $=0,18920<$ pada $t$ tabel $=1,981372$ $(\alpha: 0,05)$ sehingga keanekaragaman mikroartropoda tanah antara lahan pertanian organik dengan anorganik tidak berbeda nyata. Tingkat keanekaragaman yang sedang ini dimungkinkan karena komoditas yang saat itu tumbuh di lahan pertanian organik dan anorganik adalah tanaman tembakau.Pada daun tanaman tembakau mengandung zat nikotin yang mengeluarkan bau khas yang menyengat. Sesuai dengan pernyataan Santosa (2007), bahwa di dalam daun tembakau terdapat kandungan alkaloid nikotin yang dapat digunakan sebagai insektisida sehingga dimungkinkan mikroartropoda tanah di lahan pertanian organik dan anorganik ada yang mati atau bahkan pergi dari lahan pertanian tersebut ke tempat lain yang lebih aman.

Keanekaragaman mikroartropoda tanah di lahan pertanian anorganik $\left(H^{\prime}=2,85\right)$ lebih tinggi dibandingkan di lahan pertanian organik $\left(H^{\prime}=2,74\right)$. Rendahnya keanekaragaman di lahan pertanian organik dikarenakan keberadaan predator yang mendominasi di lahan pertanian organik juga ikut mempengaruhi berkurangnya keanekaragaman mikroartropoda tanah lain di area tersebut.

Keanekaragaman mikroartropoda tanah di lahan pertanian organik dan anorganik berbanding lurus dengan kemerataan dan kelimpahan taksa mikroartropoda tanah yang ada. Hasil perhitungan indeks kemerataan tampak di lahan pertanian organik dan anorganik menunjukkan tingkat kemerataan yang tinggi (e>0,6). Tetapi, kemerataan taksa mikroartropoda tanah di lahan pertanian anorganik $(\mathrm{e}=0,91)$ lebih tinggi dibandingkan dengan lahan pertanian organik $(\mathrm{e}=0,82)$ (Tabel 1.).

Nilai kemerataan taksa mikroartropoda tanah di lahan pertanian anorganik lebih mendekati angka 1 , artinya seluruh taksa mendekati tingkat kemerataan yang sama. Pada lahan pertanian organik nilai indeks kemerataannya lebih mendekati angka 0, artinya ada kelompok taksa mikroartropoda tanah yang mendominasi.

Walaupun kekayaan taksa mikroartropoda tanah di lahan pertanian organik lebih tinggi dibandingkan dengan anorganik, tetapi apabila kemerataannya rendah maka akan berpengaruh terhadap menurunnya keanekaragaman taksa mikroartropoda tanah karena terdapat taksa yang dominan (Tabel 1.).

Pada lahan pertanian organik terdapat taksa mikroartropoda tanah yang mendominasi tinggi hingga mencapai 26,55\%, yaitu Carabidae. Sifatnya sebagai predator memangsa mikroartropoda tanah lain dan menyebabkan jumlah taksa mikroartropoda tanah yang lain berkurang. Oleh karena itu, kemerataan taksa di lahan pertanian organik lebih rendah dibandingkan dengan lahan pertanian anorganik. Odum (1998), menyatakan bahwa keanekaragaman yang tinggi dapat ditentukan oleh tingkat kelimpahan dan kemerataan, apabila kelimpahan tinggi, sedangkan tingkat kemerataan rendah maka menurunkan nilai keanekaragaman.

Kesamaan taksa dalam komunitas mikroartropoda tanah di lahan pertanian organik dengan yang ada di lahan pertanian anorganik menunjukkan tingkat kesamaan taksa yang sedang (Tabel 1.). Hal ini dikarenakan ada faktor biotik yang mempengaruhi, yaitu interaksi antar mikroartropoda tanah dan kemiripan tipe vegetasinya 
Tabel 2. Parameterfisik tanah di lahan pertanian organik dan anorganik (rerata $\pm s d, n=3$ ).

\begin{tabular}{lrr}
\hline \multicolumn{1}{c}{$\begin{array}{c}\text { Parameter } \\
\text { Faktor Fisik }\end{array}$} & \multicolumn{1}{c}{ Organik } & \multicolumn{1}{c}{ Anorganik } \\
\hline pH Tanah & $6,5 \pm 0,06$ & $6,5 \pm 0,30$ \\
Suhu Tanah $\left({ }^{\circ} \mathrm{C}\right)$ & $27,6 \pm 2,12$ & $24,4 \pm 0,96$ \\
Intensitas Cahaya & $14.520,0 \pm 1.127,84$ & $14.586,7 \pm 4.128,06$ \\
Kadar Air (w) $\%$ & $21,0 \pm 0,10$ & $16,8 \pm 0,38$ \\
Porositas (n) $\%$ & $49,4 \pm 0,15$ & $47,4 \pm 0,19$ \\
$\quad$ Tekstur Tanah (\%) & & \\
Gravel (Kerikil) & $3,55 \pm 0,87$ & $3,28 \pm 0,61$ \\
Pasir & $62,64 \pm 0,87$ & $62,16 \pm 1,78$ \\
Silt (Debu) & $33,81 \pm 1,64$ & $34,55 \pm 1,24$ \\
\hline
\end{tabular}


Suhu tanah di lahan pertanian organik menunjukkan nilai yang lebih tinggi dibandingkan dengan suhu tanah di lahan pertanian anorganik (Tabel 2.). Hal ini dikarenakan pada lahan pertanian organik yang mengaplikasikan pupuk organik berupa pupuk kandang dan kompos terjadi proses dekomposisi bahan organik di dalam tanah yang dilakukan oleh mikroartropoda tanah seperti: Acari, Collembola, dan Leiodidae (Tabel 1.). Akibat proses dekomposisi atau pembusukan yang terjadi di dalam tanah ini menyebabkan suhu di dalam tanah naik.

Laju dekomposisi bahan organik yang dilakukan oleh mikroartropoda tanah juga bergantung pada kadar air dalam tanah yang mendukung. Kadar air dalam tanah di lahan pertanian organik dan anorganik menunjukkan nilai yang aman untuk mikroartropoda tanah hidup berkembang biak (Tabel 2.). Menurut Mukti dkk (2004), mikroartropoda tanah dapat berkembangdengan baik pada kadar air dalam tanah antara $14-25 \%$.

Faktor $\mathrm{pH}$ tanah mempengaruhi keberadaan mikroartropoda tanah. Hasil pengukuran $\mathrm{pH}$ tanah di lahan pertanian organik dan anorganik adalah 6,5 (Tabel 2.). Menurut Khairatun \& Ningsih (2013), tanaman budidaya pangan umumnya tumbuh baik pada lahan dengan $\mathrm{pH}$ tanahnya berkisar antara 5-7 dan Straalen (1998) menyatakan bahwa, mikroartropoda tanah umumnya hidup baik pada pH antara 5-7.

Tekstur tanah merupakan salah satu sifat tanah yang sangat menentukan kemampuan tanah untuk menunjang pertumbuhan pada tanaman. Tektur tanah akan mempengaruhi kemampuan tanah dalam menyimpan dan menghantarkan air, menyimpan dan menyediakan hara tanaman.

Partikel kerikil berukuran lebih dari $2 \mathrm{~mm}$ dan kasar, sehingga memiliki pori-pori tanah yang terlalu besar dan kurang baik dalam mengikat unsur hara, bahan organik, dan air dalam tanah. Persentase tekstur tanah kerikil di lahan pertanian organik dan anorganik lebih kecil dibandingkan dengan persentase tekstur pasir dan debu (Tabel 2.). Hal ini membuktikan tanah di lahan pertanian organik dan anorganik baik untuk dimanfaatkan sebagai lahan pertanian.

Tekstur berpasir di lahan pertanian organik lebih tinggi dibandingkan dengan lahan pertanian anorganik (Tabel 2.). Sebagian ruang pori pada tanah bertekstur pasir berukuran besar sehingga airasinya baik, daya hantar air cepat, tetapi kemampuan menyimpan zat hara rendah (Islami
\& Utomo, 1995). Walaupun persentase tekstur tanah pasir pada lahan pertanian organik lebih tinggi dari lahan pertanian anorganik, tetapi berdasarkan hasil uji analisis laboratorium terhadap kadar bahan organik dan unsur hara di lahan pertanian organik memiliki nilai yang lebih baik dari lahan pertanian anorganik (Tabel 3.). Hal ini dikarenakan di lahan pertanian organik mengaplikasikan pupuk organik kandang dan kompos sebagai tambahan sumber bahan organik alami di dalam tanah.

Persentase tekstur tanah debu (silt) di lahan pertanian organik lebih rendah dari lahan pertanian anorganik. Walaupun persentase tekstur debu lebih rendah tetapi dengan penambahan pupuk organik di lahan pertanian organik dapat meningkatkan kadar bahan organiknya di tanah (Tabel 3.).

Mikroartropoda tanah berperan sebagai dekomposer bahan organik dan unsur hara di dalam tanah.Proses dekomposisi dapat ditunjukkan dengan rasio C/N. Djuarnani et al., (2008),menyatakan bahwarasio $\mathrm{C} / \mathrm{N}$ pada bahan organik merupakan faktor penting dalam proses dekomposisi. Hal ini karena proses dekomposisi tergantung pada kegiatan mikrobia yang membutuhkan karbon dan nitrogen sebagai sumber energi. Jika rasio $\mathrm{C} / \mathrm{N}$ yang tinggi, maka aktivitas biologi mikroorganisme seperti pada mikroartropoda tanah (Acari dan Collembola) dalam menyelesaikan proses dekomposisi bahan organik membutuhkan waktu lebih lama.

Rasio C/N di lahan pertanian anorganik lebih tinggi dibandingkan dengan lahan pertanian organik (Tabel 3.). Walaupun hasil rasio $\mathrm{C} / \mathrm{N}$ di kedua tempat tidak berbeda jauh, tetapi ini cukup membuktikan lebih tingginya rasio $\mathrm{C} / \mathrm{N}$ di lahan pertanian anorganik menunjukkan tingkat dekomposisi yang dilakukan oleh mikroartropoda tanah lebih lama. Selain itu, pupuk kandang dan kompos sebagai bagian dari pupuk organik yang digunakan di lahan pertanian organik juga membantu mikroartropoda tanah dalam proses dekomposisi. Dekomposisi bahan organik pada pupuk kandang oleh sekelompok mikroartropooda tanah dapat menurunkan nilai rasio $\mathrm{C} / \mathrm{N}$-nya.

Pupuk organik selain dapat mengurangi kadar $\mathrm{Fe}$ di dalam tanah juga memberikan sumbangan hara makro seperti N, P, K dan unsur hara mikro lain (Khairatun \& Ningsih, 2013). Unsur hara organik Fosfor dan Kalium pada lahan pertanian organik lebih tinggi dibandingkan dengan lahan pertanian anorganik (Tabel 3.). 
Tabel 3. Parameter kimia tanah di lahan pertanian organik dan anorganik (rerata $\pm s d, n=3$ ).

\begin{tabular}{lrr}
\hline \multicolumn{1}{c}{$\begin{array}{c}\text { Parameter } \\
\text { Faktor Kimia }\end{array}$} & \multicolumn{1}{c}{ Organik } & \multicolumn{1}{c}{ Anorganik } \\
\hline Nitrogen Total $(\%)$ & $0,28 \pm 0,01$ & $0,34 \pm 0,01$ \\
C-Organik $(\%)$ & $0,25 \pm 0,01$ & $1,04 \pm 0,04$ \\
Rasio C/N & $5,96 \pm 0,14$ & $6,03 \pm 0,19$ \\
P2O5 (mg/100g) & $7,07 \pm 0,07$ & $6,50 \pm 0,16$ \\
K2O $(\mathrm{mg} / 100 \mathrm{~g})$ & $17,94 \pm 0,39$ & $14,89 \pm 0,24$ \\
Bahan Organik $(\%)$ & $17,5 \pm 0,26$ & $15,17 \pm 0,49$ \\
\hline
\end{tabular}

Unsur hara $\mathrm{P}_{2} \mathrm{O}_{5}$ merupakan bahan dasar $\mathrm{d}$ membantu proses asimilasi dan respirasi pada tanaman. Disamping itu unsur hara $\mathrm{P}_{2} \mathrm{O}_{\text {juga }}$ merangsang pertumbuhan akar yang baik. Unsur hara $\mathrm{K}_{2}$ Omemiliki peran dalam meningkatkan kekuatan batang dan mengurangi terserang penyakit (Ruhnayat, 2007). Pupuk kandang yang digunakan pada lahan pertanian organik dapat meningkatkan kandungan unsur hara $\mathbf{P}_{2} \mathrm{O}_{\mathrm{\Xi}}$ dan $\mathrm{K}_{2} \mathrm{O}$ di dalam tanah.

Unsur hara organik makro N-total di lahan pertanian anorganik lebih tinggi $(0,34 \%)$ dibandingkan dengan organik $(0,28 \%)$. Hal ini dikarenakan pemberian pupuk urea pada lahan pertanian anorganik dapat meningkatkan kadar N-total dalam tanah. Menurut Khairani (2008), bahwa urea yang diberikan ke dalam tanah akan melepas $\mathrm{H}^{+}$disekitarnya sehingga kondisi menjadi lebih masam. Pada kondisi ini ada mikroorganisme tertentu seperti bakteri Azotobacter yang tidak dapat melakukan fiksasi $\mathrm{N}$ dengan baik karena tidak toleran terhadap kondisi masam. Penurunan aktivitas Azotobacter akan memperlambat proses mineralisasi $\mathrm{N}$ dalam tanah. Oleh karena itu, kadar N-total di lahan pertanian anorganik lebih tinggi. Rendahnya $\mathrm{N}$ total pada lahan pertanian organik disebabkan karena unsur $\mathrm{N}$ banyak yang mengalir ke dasar tanah dan menguap ke udara dalam bentuk $\mathrm{N}_{2}$ akibat dari proses mineralisasi $\mathrm{N}$-total menjadi $\mathrm{N}$ tersedia oleh mikroartropoda tanah cukup lama.

Kandungan bahan organik di lahan pertanian organik lebih tinggi dibandingkan dengan lahan pertanian anorganik (Tabel 3.), bahan organik yang melimpah dapat menarikkehadiran mikroartropoda tanah.

Mikroartropoda tanah yang ditemukan di lahan pertanian organik dan berperan dalam mendekomposisi materi organik adalah Acari, Collembola, dan Leoididae (Tabel 1.). Mikroartropoda tanah melumat materi organik sehingga meningkatkan kecepatan dekomposisi (Coyne, 1999). Bahan organik yang diurai oleh mikroartropoda tanah dicampurkan dengan sisasisa bahan organik lainnya, sehingga menjadi fragmen berukuran kecil yang siap untuk didekomposisi oleh mikrobia tanah (Arief, 2001). Hasil dekomposisi oleh mikroartropoda tanah dengan mikrobia berupa humus yang mengandung nutrisi dan senyawa unsur hara yang dapat diserap oleh tanaman pertanian untuk tumbuh

\section{KESIMPULAN}

Mikroartropoda tanah di lahan pertanian organik terdapat 28 taksa dan 23 taksa di anorganik. Total kepadatan individu taksa di organik lebih tinggi $\left(2260 \mathrm{individu} / \mathrm{m}^{2}\right)$ daripada anorganik (1160individu/ $\mathrm{m}^{2}$ ). Kelimpahan taksa mikroartropoda tanah yang mendominasi tinggi di kedua lahan pertanian adalah Carabidae $(26,55 \%)$. Secara statistikkeanekaragaman mikroartropoda tanah di lahan pertanian organik dan anorganik tidak berbeda nyata.

Faktor fisik kimia lingkungan seperti kadar air, porositas, unsur hara, dan bahan organik yang tinggi mempengaruhi ditemukannya kekayaan taksa mikroartropoda tanah yang tinggi di lahan pertanian organik dibandingkan dengan anorganik dimana kekayaan taksa mikroartropoda tanah yang ditemukan rendah.

\section{UCAPAN TERIMAKASIH}

Penulis menyampaikan terima kasih kepada Tim Peneliti Ditlitabmas Dikti tahun anggaran 2015 melalui Daftar Isian Pelaksanaan Anggaran (DIPA) Nomor DIPA023.04.1.673453/2015, yang telah mengijinkan penulis untuk menjadi bagian dariTim PenelitiDitlitabmas Dikti tahun anggaran 2015dan terima kasih kepada Tim Penguji atas diskusi, saran, dan masukannya. 


\section{DAFTAR PUSTAKA}

Anggoro, T. 2003. Pengembangan Pertanian Organik. Tesis. Program Pasca Sarjana Ilmu Lingkungan. Universitas Indonesia: Jakarta.

Arief, A. 2001. Hutan dan Kehutanan. Kanisius: Jakarta.

Coleman, D.C., D.A, Crossley, Jr \& Paul, F.H. 2004. Fundamentals of Soil Ecology Second Edition. Elsevier Academic Press. Amsterdam, Boston, Heidelberg, London, New York, Oxford, Paris, San Diego, San Francisco, Singapore, Sidney, Tokyo.

Coyne, S.M. 1999. Soil Mycrobiology: An Exploratory Approach. Delmar Publishers, International Thomson Publishing Company (ITP), United Kingdom.

Doles, J.L., R.J. Zimmerman, \& J.C. Moore. 2001. Soil Microarthropod Community Structure and Dynamics In Organic and Conventionally Managed Apple Orchards In Western Colorado, USA. Applied Soil Ecology. 18.

Gliessman, S.R. 2007. Agroecology: The Ecology of Sustainable Food System. Second Edition. CRC Press: New York.

Greenslade, P., L. Deharveng, A. Bedos, \& Y.R. Suhardjono. 2000. Handbook To Collembola of Indonesia. Advisor Willem N. Ellis. Museum Zoologicum Bogoriense: Bogor.

Indriyati \& Wibowo, L. 2008. Keragaman dan Kemelimpahan Collembola serta Arthropoda Tanah di Lahan Sawah Organik dan Konvensional pada Masa Bera, J. HPT Tropika. Vol. 8 No. 2.

Islami, T. \& W.H. Utomo. 1995. Hubungan Tanah, Air, dan Tanaman. IKIP Semarang Press: Semarang.

Khairani, I. 2008. Pengaruh Kascing dan Pupuk Anorganik Terhadap Ketersediaan Nitrogen pada Alfisols Jumantono dan Serapannya Oleh Tanaman Jagung Manis (Zea mays L. saccharata). Skripsi. Jurusan Ilmu Tanah. Fakultas Pertanian. Universitas Sebelas Maret Surakarta.

Khairatun, N. \& R.D. Ningsih. 2013. Penggunaan Pupuk Organik Untuk Mengurangi Pupuk Anorganik dan Meningkatkan Produktivitas Padi di Lahan Pasang Surut. Balai Pengkajian Teknologi Pertanian (BPTP) Kalimantan Selatan.
Lee, K.E \& Pankhurst C.E. 1992. Soil Organisms and Sustainable Productivity, Aust. J. Soil Res. 30.

Mayrowani, H. 2012. Pengembangan Pertanian Organik di Indonesia. Pusat Sosial Ekonomi dan Kebijakan Pertanian: Bogor.

Mukti, C., Sugiyarto, \& M. Edwi. 2004. Keanekaragaman Mesofauna dan Makrofauna Tanah pada Berbagai Tanaman Sela di Hutan Sengon (Paraserianthes falcataria (L) Nielsen) RPH Jatirejo Kediri. Jurusan Biologi FMIPA Universitas Sebelas Maret Surakarta. B i o S M A R T: Vol. 6.

Odum, $\quad$ E.P. $\quad$ 1996. DasarDasarEkologi.Terjemahanoleh T. Samingan.GadjahMada Press: Yogyakarta. Parisi, V., C. Menta, C. Gardi, C. Jacomini, \& E. Mozzanica. 2005. Microarthropod Communities As A Tool to Assess Soil Quality and Biodiversity: A New Approach in Italy. Agriculture Ecosystems and Environment.105.

Ruhnayat, A. 2007. Penentuan Kebutuhan Pokok Unsur Hara N, P, K Untuk Pertumbuhan Tanaman Panili(Vanilla planifolia Andrews). Balai Penelitian Tanaman Obat dan Aromatik.Bul. Littro. Vol. XVIII No.1.

Sugiyarto. 2000. Pengaruh Aplikasi Bahan Organik Tanaman Terhadap Komunitas Fauna Tanah dan Pertumbuhan Kacang Hijau (Vigna radiata). Biodiversitas. 1 (1).

Sutanto, R. 2002. PenerapanPertanianOrganik. Kanisius: Yogyakarta.

Sukardi. 2012. Sehat Biaya Murah dengan Organik. Jurnal Dedikasi. 9.

Trewavas, A. 2007. Organic Farming In Perspective. http://www.agbioworld.org./argfarmperspe ctive.html. Diakses 11 November 2015.

Van Straalen, N.M., J.H. M. Schobben, \& R.G.M. de Goede. 1989. Population Consequences of Cadmium Toxicity In Soil Microarthropods, Ecotox.Environ. Safety. 17.

Wallwork, J.A. 1970. Ecology of Soil Animal. Mc. Graw Hill Book Company: London 
